Case Report

\title{
Land Use Practices in the Rural and Urban Sub Catchments of River Rwizi, Western-Uganda; Their Effect on Its Ecological Characteristics
}

\author{
Atwongyeire Doreen ${ }^{1,}$, ,Ssekandi Joseph ${ }^{2}$, Tumwesigye Wycliff ${ }^{1}$, Ndihiziwe Daniel ${ }^{3}$, \\ Nagawa Goretty ${ }^{1}$ \\ ${ }^{1}$ Faculty of Business and Development Studies, Bishop Stuart University, Mbarara, Uganda \\ ${ }^{2}$ Faculty of Agriculture, Uganda Martyrs University, Kalungu, Uganda \\ ${ }^{3}$ Faculty of Applied Science, Bishop Stuart University, Mbarara, Uganda \\ Email address: \\ atwongyeiredoreen@gmail.com (A. Doreen), sekjoseph@gmail.com (S. Joseph), wtum2012@gmail.com (T. Wycliff), \\ danielorwengo@gmail.com (N. Daniel), gnagawa@bds.bsu.ac.ug (N. Goretty) \\ ${ }^{*}$ Corresponding author
}

\section{To cite this article:}

Atwongyeire Doreen, Ssekandi Joseph, Tumwesigye Wycliff, Ndihiziwe Daniel, Nagawa Goretty. Land Use Practices in the Rural and Urban Sub Catchments of River Rwizi, Western-Uganda; Their Effect on Its Ecological Characteristics. International Journal of Energy and Environmental Science. Vol. 3, No. 2, 2018, pp. 45-50. doi: 10.11648/j.ijees.20180302.11

Received: February 9, 2018; Accepted: March 11, 2018; Published: May 4, 2018

\begin{abstract}
The water quality of river Rwizi has increasingly become a concern at community, district and national levels, serving a wider catchment in the south western part of Uganda. With the increasing national human population, there has been an increase in land use activities posing a risk of degradation. This study assessed the land use practices around river Rwizi and the effects they have on the ecological situation of the river. Cross sectional and descriptive research designs were employed in studying the effects of land use practices on the ecological characteristics of the river. Both quantitative and qualitative data analysis techniques were used in analyzing the field data. The findings indicate that several land use practices are done around the river and adverse effects have also resulted from these activities. Existing policies and laws on the management of water resources need to be strengthened. Collaborative management should be emphasized to ensure effective management of this river.
\end{abstract}

Keywords: Land Use Practices, Ecological Situation, Rural and Urban Sub Catchments

\section{Introduction}

Since time in memorial, rivers have supported human development activities by providing drinking water, enabling water transportation and providing water for irrigation. For centuries, humans have been enjoying the ecosystem services provided by rivers without understanding how the river ecosystem functions and maintains its vitality [11]. Research findings indicate that there is unequal distribution of fresh water resources on the globe which makes it impossible for most people to have access to water for use in drinking, industry, irrigation and other domestic activities [18, 17, 14]. This has resulted into water stress in many parts of the world, water degradation and conflicts from the use and management of this scarce resource.

Agriculture with all the associated land use practices impair the water quality by changing the natural characteristics of rivers, thus compromising its use for drinking, agriculture and other purposes and also depletes the water resources in these rivers [2]. Human land uses have greatly contributed to the reduction of taxa in stream ecosystems due to increased pollution, mostly those that are less tolerant to high pollution levels (Larry et al., 2008). In contrast, those that are tolerant to high levels of pollution have increased in number. This leads to the extinction of native species in these rivers [19].

It was established that surface waters in form of lagoons, 
estuaries, lakes and rivers in developing countries have been polluted through dumping of wastes because of lack of adequate sanitary facilities in these countries. It was reported that $75 \%$ of the population in these countries do that [2 and 20].

River Rwizi in Uganda is among the rivers that serve large percentage of the population, supplying water for domestic purposes, agricultural and industrial purposes [13, 7, 9]. However, the pollution loads are continually increasing in the river Rwizi catchment mainly due to industrial and domestic waste water discharge or from surface water runoff from agricultural and urban areas [21]. Poor farming methods on the unprotected hills and valleys are held responsible for this occurrence [9]. The cited land use practices have left river Rwizi in a vulnerable state with its turbidity increasing from 30 units to 110 units in dry spell, change in the flow and drying of wetlands at its fringes $[1,3]$. The river that was looked at as the glory of the western region in the 1950 s due to its ecological, economic and social vitality like the luxuriant riparian vegetation, water bucks and other aquatic life like mud fish will soon be lost if no interventions are put in place [5]. The heavy degradation of the catchment areas, inadequate water governance mechanisms, unsustainable use of water resources and related resources are greatly held accountable for this challenge [21].

A few studies like Integrated water resource management in the Rwizi basin and community conservation practices towards climate stabilization around this river have been done. However, no study has been done to quantify the level of water quality deterioration of river Rwizi as relates to land use practices.

It is under this background therefore that, the study assessed the effect of different land use practices on the ecological situation of river Rwizi. The findings of this study would contribute to designing appropriate water resource management strategies by the legislators, conservationists and the broader community.

The following questions were answered by the study;

1. Are there land use practices around river Rwizi?

2. What land use practices are practiced around river Rwizi?

3. How do the land uses practiced around river Rwizi affect its ecological situation?

\section{Materials and Methods}

\subsection{Description of the Study Area}

River Rwizi is located in western Uganda. It originates from Buhweju hills and meanders through the bare hills of southwestern Uganda in Ntungamo and Mbarara. It continues to flow eastwards via several cattle grazing areas before draining episodically into Lake Victoria. The River Rwizi Catchment runs through 5 districts including: Mbarara, Buhweju, Ntungamo, Kiruhura and Isingiro. It is the major source of economic activities in these five districts.

The river Rwizi basin covers a total surface area of 8,346 $\mathrm{km} 2$ that includes $240 \mathrm{~km} 2$ of wetlands, $207 \mathrm{~km} 2$ of forests, and $85 \mathrm{~km} 2$ of open water (IWRM Situation Analysis Report,
2007). The river is $55 \mathrm{~km}$ long and is characterized by rolling hills and is intercepted by narrow valleys.

The altitude ranges between 1300-2170 meters above sea level. Lowland areas are generally occupied by wetlands. The landscape is generally hilly especially in the south and northwest.

Four sub catchments that included Kibimba - Kamira Kyeyera, Buhanama - Nyaruteme - Nyamukana (rural sub catchments), Kashanyarazi - Nyamitanga - MUST and Kiswahili - Lugazi (urban sub catchments) were studied in depth to assess the effects that land use practices have on the ecological situation of this river.

\subsection{Research Design}

Cross sectional-descriptive design was used to characterize land use practices around river Rwizi and their effects on this river. Data was collected at one point in time and descriptive statistics were used to present the study findings [8].

\subsection{Sample size}

The sample size for the study was determined using Data was collected from 106 respondents. 100 were household heads whereas 6 were key informants that included 3 district environmental officers and 3 district agricultural officers.

\subsection{Data Collection}

Different land use practices around the river and the visible effects they have on the river's ecological situation were captured through snapshots for example the flow of the river, water color, volume and solid sedimentation in the river and turbidity. Other ecological characteristics of the river like the vegetation cover were also critically observed. An observation check list that had the key observable areas was used.

Face to face interviews were used to get information from the district natural resource officers and the agricultural officers at the district. Questions in the guide were both structured and semi structured in nature.

Questionnaire survey was used to collect data from community members that live around river Rwizi. Questionnaires had a set of both open ended and closed questions.

\subsection{Data Analysis}

The Quantitative data from questionnaires was cleaned to eliminate errors, coded and entered into a computer. The coded data was entered and analyzed using SPSS to know the land use practices that are done around river Rwizi and their effect on the river's ecological situation.

\subsection{Results}

\subsubsection{Land Use Practices Around River Rwizi}

From the data collected from the field, analysis was done and the findings were presented using appropriate descriptive statistics and charts. Below are findings from the study. 
Table 1. Land use practices around River Rwizi.

\begin{tabular}{|c|c|c|c|c|c|}
\hline \multicolumn{2}{|c|}{ Land use practices } & Frequency & Percent & Valid Percent & Cumulative Percent \\
\hline \multirow{4}{*}{ Valid } & Agric (Crop growing \& Animal rearing) & 70 & 69.3 & 71.4 & 71.4 \\
\hline & Business & 20 & 19.8 & 20.4 & 91.8 \\
\hline & Others & 8 & 7.9 & 8.2 & 100.0 \\
\hline & Total & 98 & 97.0 & 100.0 & \\
\hline Missing & System & 3 & 3.0 & & \\
\hline Total & & 101 & 100.0 & & \\
\hline
\end{tabular}

Source: Field data, 2017.

Table 1shows the land use practices around river Rwizi. Among the land use practices is agriculture including crop growing and animal rearing. It is the most commonly practiced with $69.3 \%$.

It was established from the study findings that animals which include goats and cattle are grazed at the fringes of river Rwizi. Below are photographs that were captured when some of the animals were grazing around the river banks.

Most of the crop farms were subsistence and were dominated by annual crops. Cattle rearing was done majorly in paddocks which were established near the river banks. This land use has left river banks in most sub catchments degraded severely.

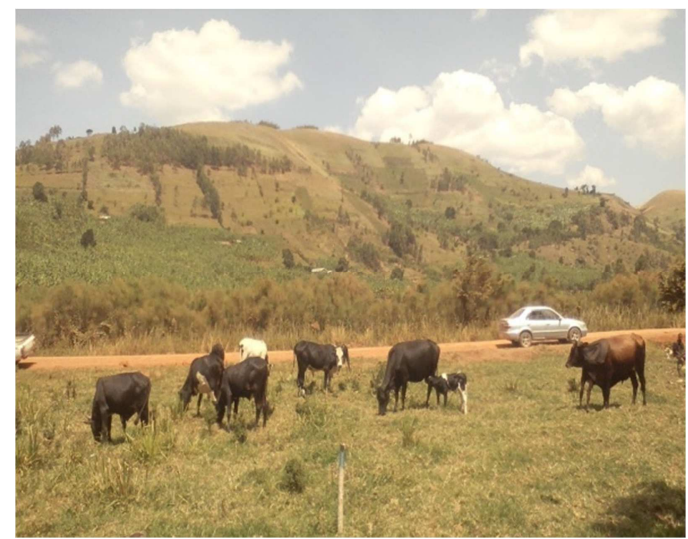

Figure 1. Cattle grazing around Nyakafumura stream one of the Rwizi sub catchments.

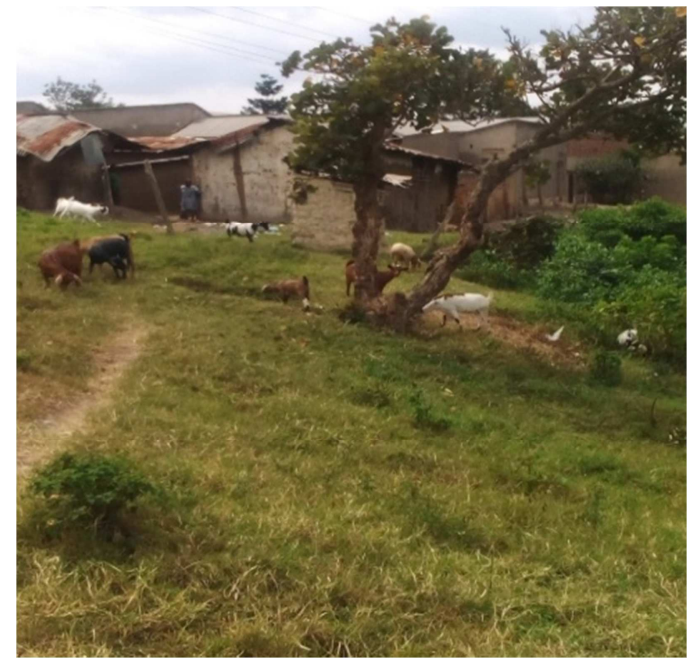

Figure 2. Goat grazing around Kashanyarazi, one of the Rwizi sub catchments.
Urban settlement was the $2^{\text {nd }}$ activity most commonly practiced around river Rwizi (19.8\%). Urbanization and industrialization were the major activity in the urban sub catchments of river Rwizi. Urban centers like Mbarara and Ntungamo were observed and industries like GBK.

Human settlements have been established either on or near the river banks. This is because land in such places is slightly cheaper as compared to other pieces of land. The practice was so common in the urban sub catchments. The natural resource officer of Mbarara district in an interview submitted that actually, people set up buildings in less than 100 meters from the river banks.

Other activities take the minority percentage (7.9). These land use practices include;

Some people were observed doing sand mining directly in the water, others gold at the steep slopes of the rural sub catchment in Buhweju whereas others were mining soil near the river banks. This is evidence that mining is one of the activities done around this river.

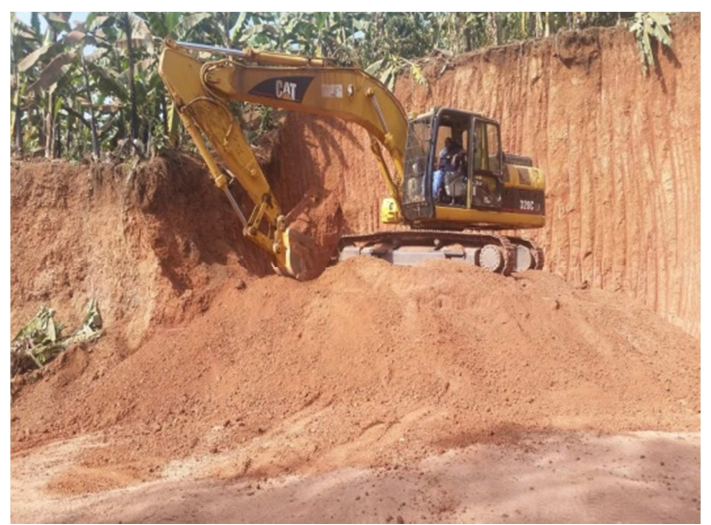

Figure 3. Soil mining around Kamira sub catchment.

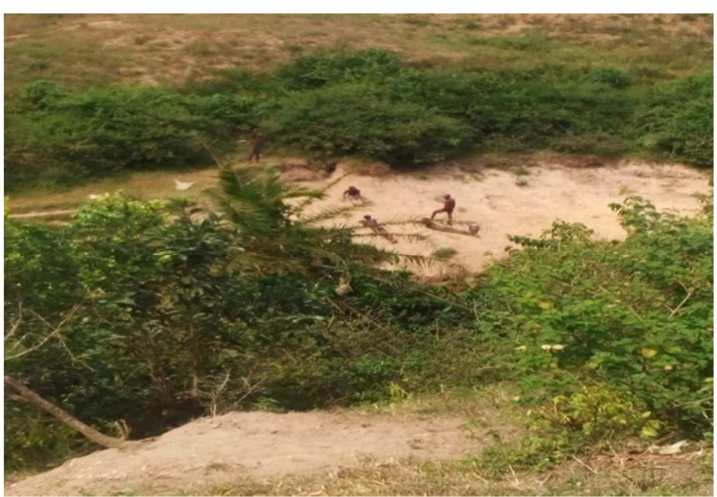

Figure 4. Sand mining at Kashanyarazi sub catchment. 
Recreation was identified as one of the land use practices around river Rwizi. This was evidenced by the photos that were taken when some men were swimming in this river.

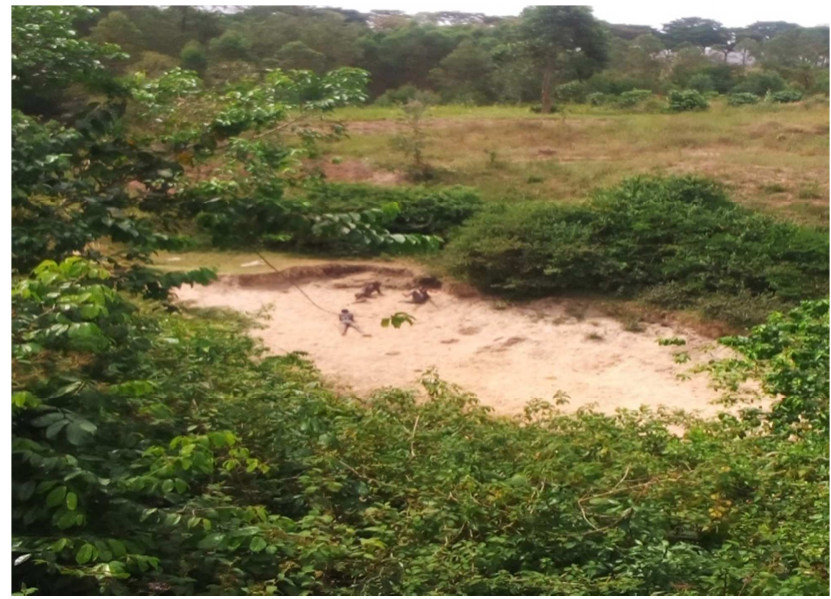

Figure 5. Recreation in form of swimming at Kashanyarazi in Mbarara.

Art and craft making is another land use practice around river Rwizi. Different crafts both for social and commercial purposes are made by communities living around river Rwizi.

The study findings also indicate that there are other land use practices done along the river though not on a large scale.

For example, brick making was observed in some areas of Buhweju around Kamira sub catchment.

Tree planting mostly eucalypts trees was observed in the rural sub catchments of the river. From the responses from the respondents, the trees are majorly for timber production. However, it is not extensively done.

The district agricultural officer of Ntungamo submitted that people had encroached on the wetland of Rwizi and planted there trees. However, the government was too quick to act and had started cutting most of the eucalyptus trees in this wetland.

Washing bays were also observed around river Rwizi in the urban sub catchments for example Baptist washing bay near Mbarara University.

Production of local brew was another activity being practiced around river Rwizi. This activity was observed at one of the tributaries of river Rwizi in the rural sub catchment.

Transport and communication were on going around river Rwizi. For example, a road from Bwizibwera to Buhweju district local government was under construction. In addition, bridges like the Katete bridge was also under construction.

\subsubsection{Effects of Land Use Practices on the Ecological Characteristics of the River}

Severe degradation was observed in most of the sub catchments that were studied. Unsustainable harvesting of wetland vegetation was recorded in many of the rural sub catchments.

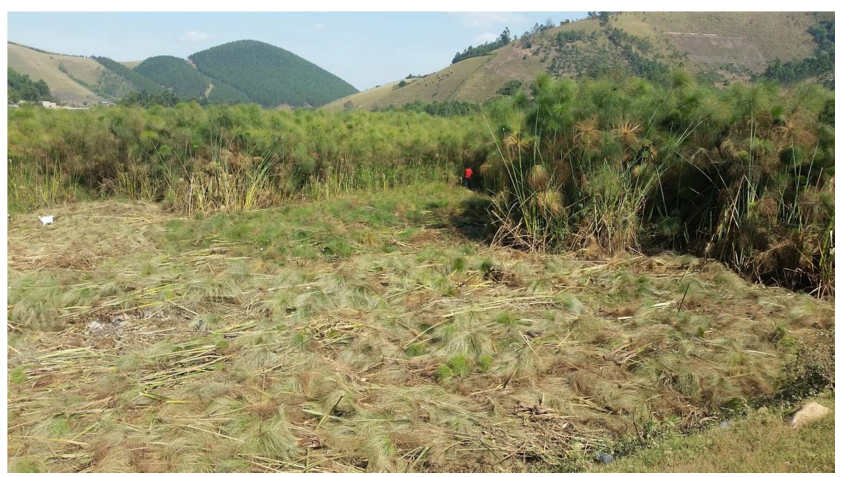

Figure 6. Wetland in Nyaruteme sub catchment heavily degraded as a result of unsustainable papyrus harvesting.

Most river banks in the rural sub catchments were encroached and used for agriculture. Animal farms were established in some of the places whereas others were used to grow annual crops like vegetables and food crops.

Where grazing is practiced on the river banks, heavy degradation of the banks in form of erosion and siltation has occurred. This has in the long run lowered the water quality of the river since the grazing animals defecate and urinate in this water.

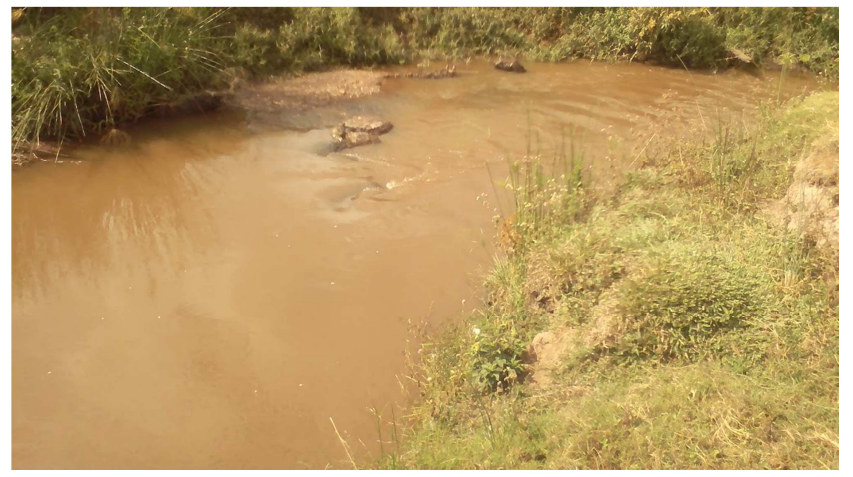

Figure 7. Water turned to brown at Nyaruteme due to erosion of the overgrazed banks.

The deterioration of the water quality of the river is also associated with the gold, sand and soil mining in the river and in the neighboring sub catchments. In the urban sub catchments, the river was used as a waste dumping site. Domestic waste and sewage were channeled to this river which in turn increased the levels of fecal coliforms and E. Coli in this water. At some points, people had defecated all around the river banks and milk films were also observed from one of the milk processing companies.

The rural households that were visited, almost each had a eucalyptus tree plantation at the banks of the river. This is very dangerous for the sustainability of the river because water uptake by this type of tress is so high thus they should not be grown along the river.

In the urban sub catchments, tree nurseries were established along the river. A lot of water is extracted for watering these nurseries. This has resulted into reduced volume of water in this river. Additionally, soil is eroded from these nursery beds to the river which results into siltation. 
Brick making around the river because of the good clay soil has been intensively practiced. This activity requires a lot of water hence lowering the water volume of the river and as the grounds for brick making are being prepared, land is left bare causing erosion and siltation of the river..

The accumulation of domestic waste in the river has led to loss of aquatic life for example mud fish. This type of fish has been in this river since the 1950's but is no more of late.

Part of the Rwizi wetland has been reclaimed in an attempt to create trannsport routes in terms of roads. This has resulted into loss of diverse wetland biodiversity in form of flora and fauna.

\subsection{Discussion}

Findings from the study indicate several land use practices around river Rwizi including among others agriculture, tree planting, urban settlement, industrialization and papyrus harvesting. These findings are in agreement with many other scholars that did their work on rivers. The arguments are clearly put down in this sub section.

There is intensive agriculture around river Rwizi in form of crop production and animal grazing. The study findings are in agreement with other scholars who submitted that crop production is the major activity around river Rwizi since people are assured of water for irrigating their crops. Both food crops like beans, maize, vegetables and cash crops in form of coffee are grown around river Rwizi [12, 16, 6].

Extensive livestock production at the banks of river Rwizi that has in the long run degraded the river through over grazing and the urination and defecation of animals in the river water was established by the study. These findings are in line with those of Songa et al [23].

The study findings indicate that urban centers are established along the river Rwizi. Similar findings indicate that urban centers are developed along river corridors to get water for domestic, commercial and industrial use. Such settlements are always put around the river since land is cheap [4 and 24]

In a submission by there is sand mining in the Rwizi wetland and also from the river bed [25]. The study findings also confirm this. These scholars add that it can be done in sand dunes and on beaches. However, there was no sand mining on the river beach as these authors submit, rather in the river bed and soil mining around the river.

The findings indicate that there is tourism and recreation along river Rwizi. Rivers are a great tourism and recreational potential because of the unique flora and fauna, waterfalls and other recreational activities that can be done. [25] again wrote that

Papyrus from the vegetation at the banks of the rivers has been harvested for several purposes including art and craft activities [26]. Various indigenous craft items like baskets, mat and sandals have been made from the papyrus vegetation at the banks of rivers [25]

These findings are in agreement with those of the study which confirmed that papyrus harvesting was extensively done in order to get raw materials for the crafts industry.
Brick making has become a serious commercial business and people lay them around river Rwizi because of the good clay soils and water availability for this activity [15]. The study shows similar findings with the above scholar.

Eucalyptus trees are the commonly planted tree species around river Rwizi [12]. This activity was confirmed by the study findings where the community members have planted eucalyptus woodlots either at the banks of the river or a few meters from the banks.

Washing bays have been established at the banks of the river in major towns and centers where the river flows through Ntale [12].This agrees with the study findings.

Papyrus around river Rwizi is harvested for several purposes which range from mulches for the banana plantations, crafts making and thatching of houses [27]. Findings from the study also confirm this.

\section{Conclusion and Recommendations}

Several land use practices are done around the river and the two dominant ones include agriculture and urban settlement. These dominant land uses practices greatly influence the ecological characteristics of river Rwizi in terms of vegetation, bank stability and the water quality.

Noticeable changes on the river's ecological situation were evidenced. Vegetation in some areas was cut and the river banks were eroded in some areas.

Some places in the sub catchments mostly the rural ones still had their natural vegetation of papyrus whereas others had lost this vegetation to different land use practices like unsustainable papyrus harvesting.

Water color in some parts of the river had deteriorated to brown due to the land use practices around whereas in some places, the volumes had also reduced.

The conservation practices in place were mainly for conserving soil and increasing food production. No priority was given to practices targeted to conserve river Rwizi.

It is very vital therefore that sustainable strategy be put in place for the conservation of this resource.

The study recommends that:

It is so vital that strengthening of the existing policies and laws as concerns resource use and management be done to reduce encroachment on the river and its resources.

Emphasis should be put on collaborative management of river Rwizi so that the local community can understand the benefit of proper resource use so as to enhance effective of the river.

\section{References}

[1] Bifubyeka E. T (2009). Five districts in water crisis over drying R. Rwizi; back up prayers with science found at http://tenbifubyeka.blogspot.com as on 24 Jun 2017 at 22:41:24 GMT

[2] Carpenter, S. R., E. M. Bennett, and G. D. Peterson (2006). Scenarios for ecosystem services: An. 
[3] Ego. Moses (2012) Heavy metal and nutrient loading of River Rwizi by effluent from Mbarara municipality, Western-Uganda.

[4] Ge Sun and Caldwell P (2015). Impacts of Urbanization on Stream Water Quantity and Quality in the United States.

[5] Government of Uganda (2010) National Development Plan; Growth, Employment and Socio-economic Transformation for Prosperity (2010/11-2014/15); Kampala, Uganda.

[6] Isabirye. M, Ruysschaert. G, Van linden. I, Poesen. J. Magunda, M. K, and Deckers. J (2007) Soil losses due to cassava and sweet potato harvesting: a case study from low input traditional agriculture. Soil Till. Res.

[7] Ministry of lands, water and environment Rehabilitating the Rwizi river catchment in Uganda.

[8] Mugenda, O. M. \&Mugenda, A. G. (2003). Research methods: Quantitative and qualitative Approaches. Nairobi: African Centre for Technology Studies.

[9] Mugira. Fredrick (2009). Drying up water bodies: A case study of river Rwizi.

[10] Mugonola. B (2013) Optimal management of farm-level resources in the Lake Victoria catchments: a case of upper Rwizi and Iguluibi micro-catchments, Uganda. KatholiekeUniversiteit Leuven Belgium.

[11] Naiman, R. J., H. Décamps, and M. E. McClain (2005). Riparia: ecology, conservation and management of streamside communities. Elsevier, San Diego, California, USA

[12] Ntale. H. K (2012) River Rwizi Water Balance Analysis, Vala Associates Ltd.

[13] OECD Annual Report (2008) found at https://www.oecd.org/newsroom as accessed on 2nd Aug 2017 at 15: 00GMT.

[14] Verhoeven Jos T. A, Regional and global concerns over wetlands and water quality: TRENDS in Ecology and Evolution Vol. 21 No. 2 February 2006.

[15] Wanyama. J (2012) Effect of land-use/cover change on land degradation in the Lake Victoria basin: the case of upper Rwizi catchment, southwestern Uganda. PhD Washington DC.
[16] Wortmann. C. S, Kaizzi. C. K (1998) Nutrient balances and expected effects of alternative practices in farming systems of Uganda.

[17] Rosegrant M. W., et al (2007) World Water and food to 2025: Dealing with Scarcity. Washington DC: International Food Policy Research Institute.

[18] Blanco, H., Alberti, M., Forsyth, A., Krizek, K. J., Rodriguez, D. A., Talen, E., et al. (2009). Hot, congested, crowded and diverse: Emerging research agendas in planning. Progress in Planning, 71 (4), 153-205.

[19] Roy, A. H., A. D. Rosemond, M. J. Paul, D. S. Leigh, And J. B. Wallace (2003) Stream macro invertebrate response to catchment urbanization (Georgia, USA). Freshwater Biology 48:329-346.

[20] United Nations Environment Programme 2009 Annual Report found at www. Digital.library.unt.edu as accessed on $30 \mathrm{Jul}$ 2017 05:55:10 GMT.

[21] Songa P., Rumohr J \&Musota R (2015). Policy And Institutional Framework Considerations In The Implementation Of Catchment-based Water Resources Management in Uganda: Highlights From the River Rwizi Catchment: WIT Transactions on Ecology and the Environment, Volume 196, Pg 12\& Published 2015.

[22] Tindimugaya C (2013). Water Management and Development Project (WMDP) 2013-2018 found at http://www.mwe.go.ug accessed on $30^{\text {th }}$ July 2017 at 15: 45 Hours.

[23] NEMA (2008). State of Environment Report Kampala Uganda.

[24] Human activities along river Rwizi found at ptajuba@ug.nationmedia.com.

[25] Castillo M. M., Morales H., Valencia E., J. J. Morales J. J \& Cruz-Mott J. J (2013). The effects of human land use on flow regime and water chemistry of headwater streams in the highlands of Chiapas: Knowledge and Management of Aquatic Ecosystems (2013) 407, 09.

[26] Verhoeven J. A. T et al 2007, Wetland restoration at the Society for Ecological Restoration International Conference in Zaragoza, Spain: ecological engineering 30 (2 00 7) 91-92.

[27] NEMA (2007). State of Environment Report Kampala Uganda. 